\title{
Increased oxidative stress in the blood of ostomy patients
}

\author{
Daniela V BAVARESC ${ }^{1,4}$, Mágada T SCHWALM ${ }^{2}$, Beatriz M de FARIAS ${ }^{2}$, Luciane B CERETTA ${ }^{3}$, \\ Maria Inês da ROSA ${ }^{4}$ and Samira S VALVASSORI ${ }^{1}$
}

Received 22/9/2017

Accepted 9/1/2018

\begin{abstract}
Background - Ostomy is a surgical procedure that creates a stoma that aims to construct a new path for the output of feces or urine. The relationship of oxidative stress (OxS) markers in patients with ostomy is still poorly described. Objective - The present study was aimed at investigating the changes in oxidative stress parameters in peripheral blood collected from ostomy patients when compared with a healthy control group. Methods - It was evaluated 29 ostomy patients and 30 healthy control patients. The oxidative stress parameters evaluated were: lipid peroxidation [lipid hydroperoxide (LPO), 8-isoprostane (8-ISO) and 4-hydroxynonenal (4-HNE)], protein oxidation and nitration [carbonyl and 3-nitrotyrosine (3-NT)] and DNA oxidation [8-hydroxy-2'-deoxyguanosine (8-OHDG)] in serum from ostomy patients compared to health controls. Results - The data showed an increase of LPO, 8-ISO, 4-HNE, 3-NT and 8-OHDG in serum collected from ostomy patients when compared to healthy controls. Conclusion - The findings support the hypothesis that ostomy triggers the oxidative stress observed in the blood collected from these patients.
\end{abstract}

HEADINGS - Surgical stomas, adverse effects. Oxidative stress. Lipid peroxidation. Nitration.

\section{INTRODUCTION}

The term Ostomy originates from the Greek designative meaning mouth or opening, and is used to indicate the externalization of any hollow viscera through the body for various causes. It is a surgical procedure in which various body segments are given different names. There are routes for fecal and urinary elimination (frequent in clinical practice), and others such as gastrostomy, tracheostomy and esophagostomy, all of which have different purposes and directions ${ }^{(1)}$. This article focuses on the ostomy relating to fecal and urinary elimination. There are several reasons why a person will need to be operated on to build a stoma, such as in colon or rectal cancer, diverticulitis with severe peritonitis, intestinal infarction, severe trauma and also in complex anal problems; among the more common incidents are colorectal cancer and diverticular disease ${ }^{(2)}$. The United Ostomy Association of America (UOAA) ${ }^{(3)}$ estimates that around 750.000 to 1.000 .000 people in the United States are living with an ostomy (access in 2016), with approximately 100.000 people undergoing operations each year ${ }^{(4)}$.

There are two main types of ostomy, fecal and urinary, which can be divided in permanent or temporary ${ }^{(5)}$. Colostomy is performed in the large intestine ${ }^{(6)}$; the ileostomy is performed in the small bowel ${ }^{(7)}$, and finally, the urostomy consists of redirecting the normal course of urine, which is similar to an intestinal stoma ${ }^{(8)}$.

The relationship of oxidative stress $(\mathrm{OxS})$ markers in patients with ostomy is still poorly described. Findings are mostly from preclinical studies, which have described oxidative deoxyribonucleic acid (DNA) damage ${ }^{(9-1)}$. The colonoscopy leads to a significant increase in the levels of oxidative DNA damage in colon segments without transit, when compared with segments which have fecal stream, independent of the duration of exclusion ${ }^{(11)}$. OxS refers to an imbalance between pro-oxidants and antioxidant agents. Therefore, there is an increase in the production of reactive oxygen species (ROS). Antioxidant mechanisms or changes can lead to damage to cellular components such as DNA, proteins and lipids ${ }^{(12)}$. Besides ROS, there are also the reactive nitrogen species (RNS), such as nitric oxide (NO) and peroxynitrite (ONOO), which can also induce damage to biomolecules ${ }^{(13,14)}$.

In this context, the present study was aimed at investigating the changes in oxidative stress parameters (Lipid hydroperoxide, Carbonyl, 3-nitrotyrosine, 8-isoprostane, and 4-hydroxynonenal) in peripheral blood taken from ostomy patients when compared to those collected from subjects in a healthy control group.

\section{METHODS}

\section{Subjects}

The present study was approved by the Ethics Committee of the Universidade do Extremo Sul Catarinense (UNESC), protocol number: 787.325 , in accordance with the recommendations of the Declaration of Helsinki and the resolution $n^{\circ} 196 / 96$ of the National Health Council on research involving humans. The study evaluated 29 ostomy patients and 30 healthy control patients, recruited from among those enrolled in the Nursing Clinic of the UNESC, located in the city of Criciúma, Brazil. Patients were only included in the study after signing the Subject Information and Consent Form.

Declared conflict of interest of all authors: none

Disclosure of funding: no funding received

${ }_{1}^{1}$ Universidade do Extremo Sul Catarinense, Unidade Acadêmica de Ciências da Saúde, Programa de Pós-Graduação em Ciências da Saúde, Laboratório de Sinalização Neural e Psico-farmacologia Criciúma, SC, Brasil. ${ }^{2}$ Universidade do Extremo Sul Catarinense, Unidade Acadêmica de Ciências da Saúde, Curso de Enfermagem, Criciúma, SC, Brasil. ${ }^{3}$ Universidade do Extremo Sul Catarinense, Unidade Acadêmica de Ciências da Saúde, Programa de Pós-Graduação em Saúde Coletiva, Laboratório de Saúde Coletiva, Criciúma, SC, Brasil. ${ }^{4}$ Universidade do Extremo Sul Catarinense: Laboratório de Epidemiologia; Programa de Pós-Graduação em Saúde Coletiva; Programa de Pós-Graduação em Ciências da Saúde, Criciúma, SC, Brasil.

Corresponding author: Samira S Valvassori. E-mail: samiravalvassori@unesc.net 


\section{Sample collection}

From each subject, $10 \mathrm{ml}$ of peripheral blood were drawn by venipuncture into a vacuum tube. The blood was immediately centrifuge at $3000 \mathrm{xg}$ for $5 \mathrm{~min}$, and the serum was stored at $-80^{\circ} \mathrm{C}$ for subsequent assay. Total protein was measured by Lowry and colleagues (1951) method using bovine serum albumin as a standard.

\section{Lipid hydroperoxide of peripheral blood (LPO)}

For the quantitative measurement of LPO (Enzyme-Linked Immunosorbent Assay) in serum of peripheral blood mononuclear cells was used ELISA kit Cayman Chemical Company (No. 705003).

\section{Protein carbonyl content of peripheral blood}

For the quantitative measurement of protein carbonyl (Enzyme-Linked Immunosorbent Assay) in serum of peripheral blood mononuclear cells was used ELISA kit Cell Biolabs, INC. (STA-310-5).

\section{3-nitrotyrosine of peripheral blood}

For the quantitative measurement of 3-nitrotyrosine (EnzymeLinked Immunosorbent Assay) in serum of peripheral blood mononuclear cells was used ELISA kit Cell Biolabs, INC. (STA-305-5).

\section{8-isoprostane of peripheral blood}

For the quantitative measurement of 8-isoprostane (EnzymeLinked Immunosorbent Assay) in serum of peripheral blood mononuclear cells was used ELISA kit Cayman Chemical Company (No. 516351).

\section{4-hydroxynonenal of peripheral blood}

For the quantitative measurement of 4-hydroxynonenal (Enzyme-Linked Immunosorbent Assay) in serum of peripheral blood mononuclear cells was used ELISA kit Cell Biolabs, INC. (STA-334-5).

\section{8-OH-deoxyguanosine of peripheral blood}

For the quantitative measurement of 8-OH-deoxyguanosine (8-OHdG) (Enzyme-Linked Immunosorbent Assay) in serum of peripheral blood mononuclear cells was used ELISA kit Cell Biolabs, INC. (STA-320-5).

\section{Statistics}

Data were analyzed using the Statistical Package for Social Sciences (SPSS) software, version 22.0 (IBM Corporation, Armonk, NY, USA). Normality distribution of data was determined using of biochemical data was examined by Shapiro-wilk test. Biochemical test showed normal distribution in the statistical test. To identify the differences between groups (ostomy versus healthy control patients) of biochemical variables we used Student $t$ test. For the non-parametric variable used the Wilcoxon test. In the characteristics of the patients used Fisher's exact test. Differences were considered significant $P$ values $\leq 0.05$.

\section{RESULTS}

The TABLE 1 showed characteristics of the ostomy patients when compared to healthy control, the data indicated groups were homogeneous regarding age, gender, smoking, alcoholic, other diseases, and menopause and hormone replacement therapy in
TABLE 1. Characteristics of the patients.

\begin{tabular}{|c|c|c|c|}
\hline \multirow[b]{2}{*}{ Variables } & \multicolumn{3}{|c|}{ Patients } \\
\hline & $\begin{array}{c}\text { Ostomy } \\
(\mathrm{n}=29)\end{array}$ & $\begin{array}{c}\text { Control } \\
(\mathrm{n}=30)\end{array}$ & $P$-value \\
\hline \multicolumn{4}{|l|}{ Gender } \\
\hline Male, n (\%) & $10(34.5)$ & $5(16.7)$ & \multirow{2}{*}{$0.116^{a}$} \\
\hline Female, n $(\%)$ & $19(65.5)$ & $25(83.3)$ & \\
\hline Age, mean \pm SD & $58.52( \pm 18.3)$ & $57.30( \pm 12.9)$ & $0.696^{\mathrm{b}}$ \\
\hline \multicolumn{4}{|l|}{ Conjugal Situation } \\
\hline Single, $\mathrm{n}(\%)$ & $3(10.3)$ & $1(3.3)$ & \multirow{4}{*}{$0.015^{* c}$} \\
\hline Married, n (\%) & $11(37.9)$ & $20(66.7)$ & \\
\hline Widowed, n (\%) & $6(20.7)$ & $8(26.7)$ & \\
\hline Other, n (\%) & $9(31.0)$ & $1(3.3)$ & \\
\hline \multicolumn{4}{|l|}{ Occupation } \\
\hline Housewife, n (\%) & $2(6.9)$ & $7(23.3)$ & \multirow{4}{*}{$0.0012^{*}$} \\
\hline Retired, n (\%) & $16(55.2)$ & $13(43.3)$ & \\
\hline Disease aid, n (\%) & $8(27.6)$ & $0(0)$ & \\
\hline Other, n $(\%)$ & $3(10.3)$ & $10(33.3)$ & \\
\hline \multicolumn{4}{|l|}{ Smoker } \\
\hline Yes, n (\%) & $5(17.2)$ & $4(13.3)$ & \multirow{2}{*}{$0.676^{a}$} \\
\hline No, n $(\%)$ & $24(82.8)$ & $26(86.7)$ & \\
\hline \multicolumn{4}{|l|}{ Alcoholic } \\
\hline Yes, n (\%) & $1(3.4)$ & $1(3.3)$ & \multirow{2}{*}{$0.980^{\mathrm{a}}$} \\
\hline No, n $(\%)$ & $28(96.6)$ & $29(96.7)$ & \\
\hline \multicolumn{4}{|l|}{ Sexual activity } \\
\hline Yes, n $(\%)$ & $11(37.9)$ & $19(63.3)$ & \multirow{2}{*}{$0.051^{\mathrm{a}}$} \\
\hline No, n (\%) & $18(62.1)$ & $11(36.7)$ & \\
\hline
\end{tabular}

Comorbidities

Systemic Arterial

Hypertension, n (\%)

8 (27.6) $\quad 5(16.7)$

Diabetes Mellitus, n (\%)

$0(0)$

$1(3.3)$

Pneumopathies, n (\%)

$1(3.4)$

$1(3.3)$

Rheumatopathies, n (\%)

2 (6.9)

$2(6.7)$

Other, n (\%)

$4(13.8)$

$4(13.3)$

Systemic arterial

hypertension and

2 (6.9)

$15(50.0)$

(

Without comorbidities,

n $(\%)$

$12(41.4)$

$2(6.7)$

\section{Menopause}

$\begin{array}{lcc}\text { Yes, } \mathrm{n}(\%) & 11(37.9) & 13(43.3) \\ \text { No, n }(\%) & 8(27.6) & 11(36.7) \\ \text { Not applicable, n (\%) } & 10(34.5) & 5(20.0)\end{array}$

$0.642^{c}$

Hormone replacement therapy

\begin{tabular}{lccc} 
Yes, n $(\%)$ & $2(6.9)$ & $1(3.3)$ & \\
No, n (\%) & $17(58.6)$ & $23(76.7)$ & $0.416^{\mathrm{a}}$ \\
Not applicable, n (\%) & $10(34.5)$ & $5(20.0)$ & \\
\hline
\end{tabular}

SD: standard deviation. Datas are expressed as $\%$ of patients. *Differences between ostomy versus control patients, $P \leq 0.05$ were considered to be statistical significant. ${ }^{a}$ Chi-square test; ${ }^{\mathrm{b}}$ Independent-samples $\mathrm{t}$ test, data are expressed as mean $\pm \mathrm{SD} ;{ }^{c}$ Fisher's exact test. 
the women. Had a significant difference between the groups, the variables conjugal situation, and occupation; these variables do not interfere with the biochemical parameters. The TABLE 2 were describes the characteristics of the ostomy patients. The median of ostomy time was 26 months and interquartile range (IQL) 11.0-62.5. The most predominant type of ostomy was colostomy $(\mathrm{n}=23 ; 79.3 \%) .22(75.8 \%)$ patients had cancer as the leading cause of ostomy, followed by diverticulitis $(n=3 ; 10.3 \%)$. Variable reversal attempts indicated $25(86.2 \%)$ patients not tried reversing the ostomy. $22(75.9 \%)$ patients reported to used one piece. 17 patients $(58.6 .7 \%)$ reports have no skin lesions. The most predominant of

TABLE 2. Characteristics of the ostomy patients $(n=29)$

\begin{tabular}{|c|c|}
\hline Variables & \\
\hline Ostomy time (months), MDN (IQR) & $26.0(11.0-62.5)$ \\
\hline \multicolumn{2}{|l|}{ Type of ostomy } \\
\hline Colostomy, n (\%) & $23(79.3)$ \\
\hline Ileostomy, n (\%) & $4(13.3)$ \\
\hline Urostomy, n (\%) & $1(3.3)$ \\
\hline Colostomy+Urostomy, n (\%) & $1(3.3)$ \\
\hline \multicolumn{2}{|l|}{ Cause of ostomy } \\
\hline Diverticulitis, n (\%) & $3(10.3)$ \\
\hline Cancer, n $(\%)$ & $22(75.8)$ \\
\hline Abscess anal, n (\%) & $1(3.4)$ \\
\hline Drilling recto sigmoid, $\mathrm{n}(\%)$ & $1(3.4)$ \\
\hline Other functional bowel disorders, $\mathrm{n}(\%)$ & $1(3.4)$ \\
\hline Sigmoid colon, n (\%) & $1(3.4)$ \\
\hline \multicolumn{2}{|l|}{ Type of ostomy pouch } \\
\hline One piece, $\mathrm{n}(\%)$ & $22(75.9)$ \\
\hline Two pieces, n (\%) & $7(24.1)$ \\
\hline \multicolumn{2}{|l|}{ Reversal attempts } \\
\hline Yes, n $(\%)$ & $4(13.8)$ \\
\hline No, n $(\%)$ & $25(86.2)$ \\
\hline \multicolumn{2}{|l|}{ Skin lesions } \\
\hline Yes, n (\%) & $12(41.4)$ \\
\hline No, n $(\%)$ & $17(58.6)$ \\
\hline \multicolumn{2}{|l|}{ Change in life habits after ostomy } \\
\hline Yes, $\mathrm{n}(\%)$ & $22(75.9)$ \\
\hline No, n $(\%)$ & $7(24.1)$ \\
\hline \multicolumn{2}{|l|}{ Change of clothes after ostomy } \\
\hline Yes, n $(\%)$ & $16(55.2)$ \\
\hline No, n (\%) & $13(44.8)$ \\
\hline \multicolumn{2}{|l|}{ Complications of ostomy } \\
\hline Dermatitis, n (\%) & $3(10.7)$ \\
\hline Flat stoma, n (\%) & $1(3.6)$ \\
\hline Hernia, n $(\%)$ & $7(25.0)$ \\
\hline Fistula, n (\%) & $2(7.1)$ \\
\hline Prolapse, n (\%) & $1(3.6)$ \\
\hline Others, n (\%) & $2(7.1)$ \\
\hline Hassle free, n (\%) & $13(42.9)$ \\
\hline \multicolumn{2}{|l|}{ Presence of diarrhea } \\
\hline Yes, n (\%) & $6(20.7)$ \\
\hline No, n $(\%)$ & $23(79.3)$ \\
\hline
\end{tabular}

MDN: median; IQR: interquartile range. patients do not has complications due to ostomy ( $n=13 ; 42.9 \%)$. The TABLE 3 were describes oxidative stress levels, subdividing the ostomized group with: cancer and without cancer. No significant differences were found in the assessment suggesting that these changes were not due to cancer.

TABLE 3. Oxidative stress parameters.

\begin{tabular}{lccc}
\hline $\begin{array}{l}\text { Oxidative } \\
\text { stress } \\
\text { parameters }\end{array}$ & $\begin{array}{c}\text { Ostomy - } \\
\text { cancer }(\mathbf{n}=22)\end{array}$ & $\begin{array}{c}\text { Ostomy - without } \\
\text { cancer }(\mathbf{n}=\mathbf{0 7})\end{array}$ & $\boldsymbol{P}$-value \\
\hline $\begin{array}{l}\text { 4-HNE, mean } \\
\pm \mathrm{SD}\end{array}$ & $37.86( \pm 3.18)$ & $38.28( \pm 1.70)$ & 0.106 \\
$\begin{array}{l}\text { 8-OHdG, mean } \\
\pm \mathrm{SD}\end{array}$ & $32.05( \pm 2.89)$ & $32.29( \pm 2.14)$ & 0.125 \\
$\begin{array}{l}\mathrm{LPO}, \text { mean } \pm \\
\text { SD }\end{array}$ & $12.24( \pm 4.02)$ & $14.10( \pm 4.97)$ & 0.190 \\
$\begin{array}{l}8 \text {-isoprostane, } \\
\text { mean } \pm \text { SD }\end{array}$ & $152.64( \pm 5.77)$ & $151.43( \pm 4.16)$ & 0.320 \\
$\begin{array}{l}\text { Carbonyl, mean } \\
\pm \text { SD }\end{array}$ & $10.84( \pm 2.93)$ & $10.51( \pm 1.93)$ & 0.251 \\
$\begin{array}{l}\text { 3-nitrotyrosine, } \\
\text { mean } \pm \text { SD }\end{array}$ & $158.32( \pm 20.98)$ & $177.14( \pm 22.94)$ & 0.986 \\
\hline
\end{tabular}

Independent-samples $t$ test, data are expressed as mean $\pm \mathrm{SD}$, differences between ostomy versus control patients, $P<0.05$ were considered to be statistical significant.

In the FIGURE 1, it can be observed parameters of lipid damage. It was found an increase of lipid hydroperoxide (LPO) $(\mathrm{t}=8.46, \mathrm{df}=58 \quad P<0.001)($ FIGURE 1A) 4-hydroxynonenal (4-HNE) $(\mathrm{t}=27.58, \mathrm{df}=58, P<0.001)($ FIGURE 1B), and 8-isoprostane $(\mathrm{t}=59.70, \mathrm{df}=58, P<0.001)($ FIGURE $1 \mathrm{C})$ in serum from ostomy patients compared to health controls.

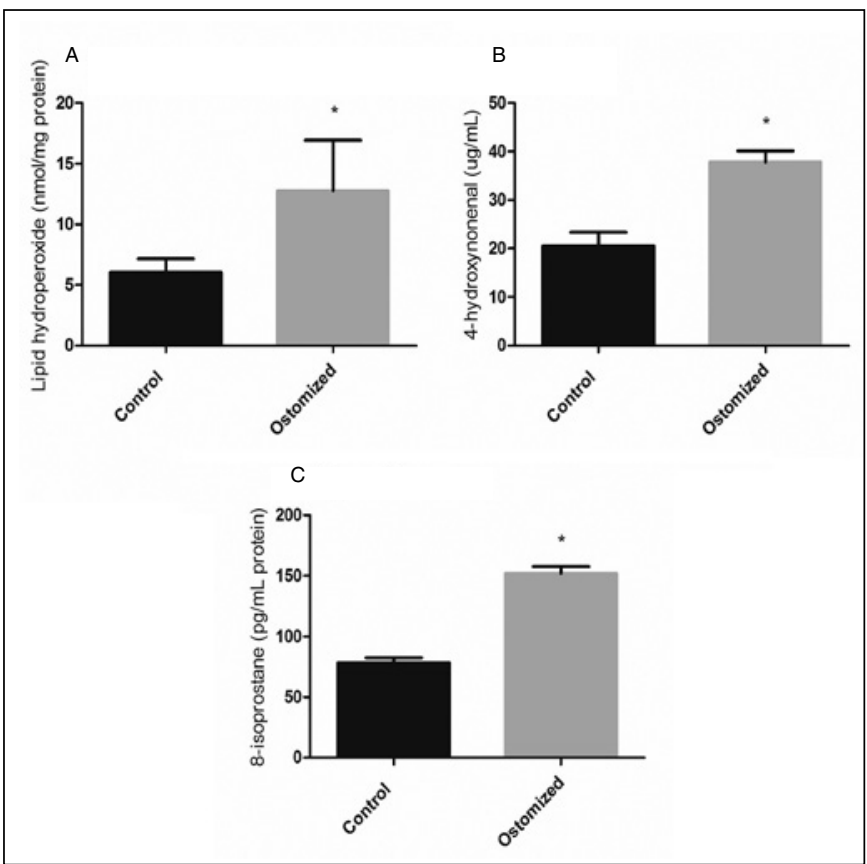

FIGURE 1. Lipid oxidation parameters in serum from ostomy patients compared to health controls. Lipid hydroperoxide (LPO) (A), 4-hydroxynonenal (4-HNE) (B), and 8-isoprostane (C). The results are expressed as the mean $+\mathrm{SD}$. *Differences between ostomy patients versus health controls. $P \leq 0.05$ were considered to be statistical significant from $t$ test. 
In the FIGURE 2, it can be observed parameters of protein damage. It was found an increase of protein carbonylation $(\mathrm{t}=13.10$, $\mathrm{df}=58, P<0.001)($ Figure $2 \mathrm{~A})$ and 3-nitrotyrosine $(\mathrm{t}=17.89, \mathrm{df}=58$, $P<0.001)$ (FIGURE 2B), a product of protein tyrosine nitration, in serum from ostomy patients compared to health controls.

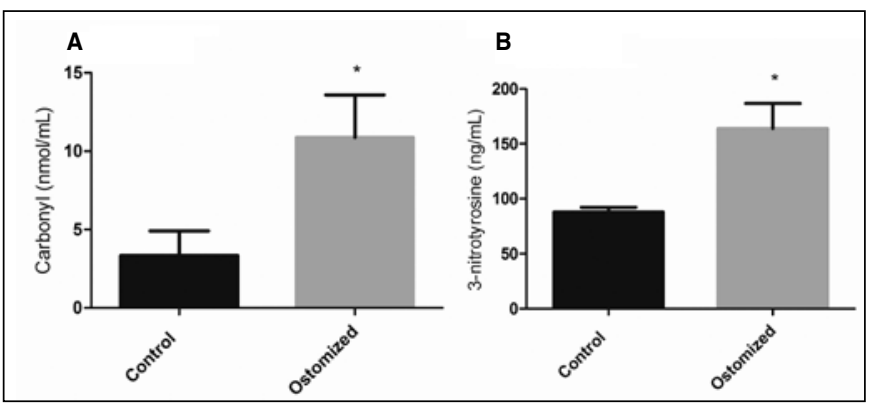

FIGURE 2. Protein damage parameters in serum from ostomy patients compared to health controls. Protein carbonylation (A) and 3-nitrotyrosine (B). The results are expressed as the mean $+\mathrm{SD}$. *Differences between ostomy patients versus health controls. $P \leq 0.05$ were considered to be statistical significant from $t$ test.

In the FIGURE 3, it can be observed parameters of DNA damage. It was found an increase of $8-\mathrm{OHdG}(\mathrm{t}=26.87, \mathrm{df}=59, P<0.001)$ in serum from ostomy patients compared to health controls.

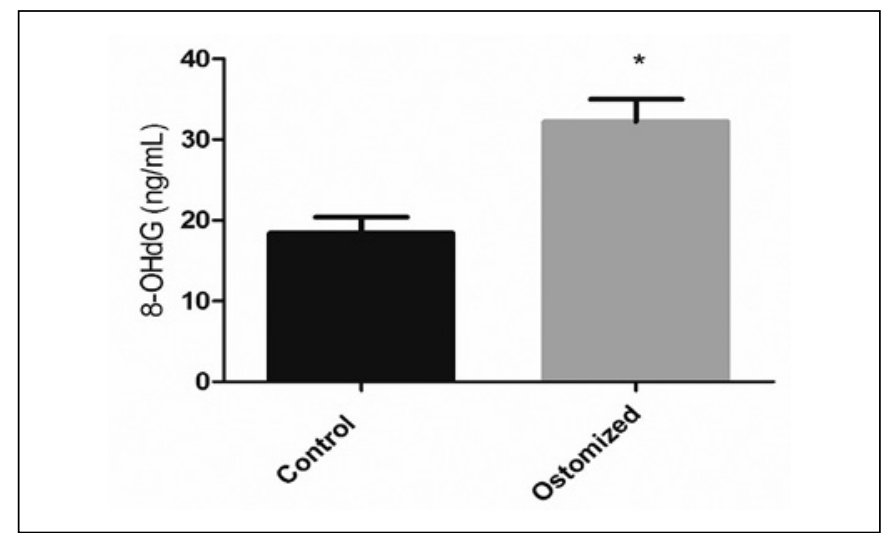

FIGURE 3. DNA damage parameters (8-OHdG) in serum from ostomy patients compared to health controls. The results are expressed as the mean $+\mathrm{SD}$. *Differences between ostomy patients versus health controls. $P \leq 0.05$ were considered to be statistical significant from $t$ test.

\section{DISCUSSION}

The investigation of peripheral parameters of oxidative stress in ostomy patients is still poorly described in the literature. The present study is the first to provide evidence of a significant increase in lipid peroxidation and protein damage in ostomy patients. It was observed that there was an increase of lipid hydroperoxide, 8-isoprostane, 4-HNE, protein carbonyl, 3-nitrotyrosine, and 8-OHdG in the serum from ostomy patients when compared to the healthy control patients.

The LPO quantification is widely used as a marker of lipid peroxidation, which occurs in response to oxidative stress, as a great diversity of different aldehydes are formed when lipid hydroperoxides break down within a biological system ${ }^{(15)}$. Lipid peroxidation results in the formation of highly reactive and unstable hydroperoxides of both satured and unsatured lipids, measured by 4-HNE, which is a measure of polyunsaturated fatty acids (PUFs) and hydroperoxides ${ }^{(16)}$. The 8-isoprostane belongs to the family of eicosanoids, which are of non-enzymatic origin and produced by the random oxidation of tissue phospholipids by oxygen radicals ${ }^{(17)}$. Protein damage may be caused by the reactions of amino acid residues with ROS, especially $\mathrm{OH} \bullet$, catalyzed by $\mathrm{Fe}^{2+}$ and cupric $\left(\mathrm{Cu}^{2+}\right)$, which introduces carbonyl groups in lysine, proline, arginine, and threonine residues, thus the quantification of carbonyl groups is a marker of oxidative damage to proteins ${ }^{(18,19)}$. 3-nitrotyrosine is a specific biomarker of protein nitration, because it reacts with peroxynitrite, which is the most harmful product created by the reaction between nitric oxide and superoxide anion ${ }^{(20)}$. DNA is probably the most biologically significant target of oxidative attack. The most common marker of oxidative DNA damage is $8-\mathrm{OHdG}$, which plays an essential role in the induction of spontaneous mutations, and is the most representative product of oxidative modifications of DNA. The formation of $8-\mathrm{OHdG}$ is a ubiquitous marker of oxidative stress, and one of the byproducts of oxidative DNA damage ${ }^{(21,22)}$.

As pointed out earlier, the present study is the first to discussed relationship between ostomy and oxidative stress parameters. The biochemistry effects of ostomy is poor related in the literature, and the studies related to ostomy and oxidative stress are still limited to animal model. Therefore, more studies are necessary to improve the knowledge about this condition. In a previous preclinical study, which utilized an animal model of diversion colitis, Wistar rats were subjected to a deviation of the fecal stream by proximal colostomy and a distal mucosal fistula, after which the authors evaluated the levels of oxidative DNA damage to epithelial colon cells, comparing segments with and without fecal stream. It was demonstrated that rats which had colon segments without a fecal stream had a higher histological inflammatory response that increased with the time of diversion. The activity of myeloperoxidase in segments without fecal stream decreased over the same period of time. In addition, the same study also demonstrated that the levels of oxidative DNA damage were significantly higher in the segments without fecal stream, regardless the length of time that the colon diversion was maintained for, and showed that this damage increased with time $^{(11)}$. In the present study, it was shown that ostomy induced DNA damage in the serum collected from ostomy patients. Since $80 \%$ of the patients in this study have colostomy, it can be suggested that the damage to the colon epithelium may be extended to the serum from ostomy patients.

In another study, Longatti et al. ${ }^{(23)}$ evaluated the temporal inflammatory alterations in the refunctioned colon of rats by analyzing their histological results, infiltrating neutrophils, proinflammatory markers such as cyclooxygenase (COX)-2 and inducible nitric oxide synthase (iNOS), and DNA damage in isolated colonocytes. This was undertaken in an animal model using surgical techniques to divert the fecal stream, and with colitis induced by 2,4,6-trinitrobenzene sulfonic acid. The authors suggested that through the inflammatory course, DNA damage could be associated with neutrophil infiltration and the generation of cytokine and ROS by neutrophils.

The deleted intestinal segment of the fecal stream can present inflammatory processes as diversion colitis, which is described as an inflammatory process that occurs in the colorectal segments excluded from the fecal stream ${ }^{(24)}$. This is characterized by the infiltration of white blood cells into the colonic mucosa, resulting in tissue destruction ${ }^{(25)}$. The deficiency of short-chain fatty acids inside 
the intestinal lumen was considered the main etiologic factor. Once damaged, the epithelial barrier is no longer able to exclude highly immunogenic fecal bacterial antigens from invading the normally sterile submucosal tissue ${ }^{(24)}$. The absence of passing fecal matter is an intestinal biological imbalance which may cause a change in the energy metabolism of the epithelial cells, thus leading to excessive $\operatorname{ROS}^{(25)}$. Activated neutrophils produce reactive oxygen and nitrogen species within the intestinal mucosa, which induces' oxidative stress $^{(26)}$, with hydrogen peroxide to be considered a primary etiologic agent in the pathogenesis ${ }^{(25)}$. The initial process for a trigger of colitis occurs at the interface between the epithelial cells and the basement membrane via excessive ${ }^{(25-28)}$. Together these studies suggest that in inflammatory conditions reactive oxygen species are produced, contributing to proteins, DNA and lipids damage.

\section{CONCLUSION}

In conclusion the present study is the first to provide evidence of a significant increase in oxidative damage to lipid, DNA and protein, evaluated through of markers: LPO, 8-isoprostane, 4-HNE, protein carbonyl, 3-nitrotyrosine, and $8-\mathrm{OHdG}$ in the serum from ostomy patients when compared to the healthy control patients. More studies are needed to analyze the long-term damage of oxidative stress and its consequences in the body of patients with ostomy.

\section{Limitations of study}

The main limitation of this study was the lack of a cancer group without ostomy, as the cancer itself also leads to oxidative stress. For such questions we performed an evaluation subdividing the ostomized group with: cancer and without cancer; we did the statistical analysis through Independent-samples t test, did not present significant difference. Excluding the possibility that the parameters of oxidative stress evaluated in ostomized patients are of cancer origin. In addition, a longer period of monitoring with further analysis of oxidative stress parameters can help to predict whether oxidative stress is associated with the severity of the disease, and the possible reversal of the ostomy. Therefore, further studies are needed to help us discover the true relationship between ostomy and oxidative stress. Another important limitation of the present study was the lack of analysis of how many patients had inflammation due to intestinal disuse.

\section{ACKNOWLEDGEMENTS}

\author{
We thank CNPq, FAPESC, CAPES and UNESC for financial
} support.

\section{Authors' contribution}

Valvassori SS, Schwalm MT and, Ceretta LBdesigned the study and wrote the protocol. Bavaresco DV and, Rosa MI managed the literature searches and analyses. Farias BM and, Valvassori SS undertook the experimental procedures and, biochemical analysis. Bavaresco DV and, Rosa MI undertook the statistical analysis. Bavaresco DV, Rosa MI and, Valvassori SS, and wrote the first draft of the manuscript. All authors contributed to and have approved the final manuscript.

Bavaresco DV, Schwalm MT, Farias BM, Ceretta LB, Rosa MI, Valvassori SS. Aumento de estresse oxidativo no sangue de pacientes com ostomia. Arq Gastroenterol. 2018;55(2):164-9.

RESUMO - Contexto - Ostomia é um procedimento cirúrgico que cria um estoma com objetivo de construir um novo caminho para a saída das fezes ou urina. A relação dos marcadores de estresse oxidativo em pacientes ostomizados ainda é pouco descrita. Objetivo - O presente estudo tem como objetivo investigar as alterações dos parâmetros de estresse oxidativo em sangue de pacientes ostomizados comparados a controles saudáveis. Métodos - Foram avaliados 29 pacientes ostomizados e 30 controles saudáveis. Os parâmetros de estresse oxidativo avaliados foram: peroxidação lipídica [hidroperóxido de lipídio (LPO), 8-isoprostano (8-ISO) e 4-hidroxinonenal (4-HNE)], oxidação e nitração de proteínas [carbonila e 3-nitrotirosina (3-NT)] e oxidação do DNA [8-hidroxi-2'-desoxiguanosina (8-OHDG)] em soro de pacientes ostomizados comparados a controles saudáveis. Resultados - Os dados mostraram um aumento de LPO, 8-ISO, 4-HNE, 3-NT e 8-OHDG em soro de pacientes ostomizados em comparação a controles saudáveis. Conclusão - Os achados sustentam a hipótese de que a ostomia desencadeia o estresse oxidativo observado no sangue coletado destes pacientes.

DESCRITORES - Estomas cirúrgicos, efeitos adversos. Estresse oxidativo. Peroxidação de lipídeos. Nitração.

\section{REFERENCES}

1. Weakley FL. A historical perspective of stomal construction. J Wound Ostomy Continence Nurs. 1994;21:59-75.

2. Sandler RS, Everhart JE, Donowitz M, Adams E, Cronin K, Goodman C, et al The burden of selected digestive diseases in the United States. Gastroenterology. 2002;122:1500-11.

3. United Ostomy Association of America. Phoenix Ostomy Chapter: ostomy information. Available from: www.ostomy.org/About_the_UOAA.html. Accessed February 23,2016.

4. Ostomy Guidelines Task Force, Goldberg M, Aukett LK, Carmel J, Fellows J, Folkedahl B, et al. Management of the patient with a fecal ostomy: best practice guideline for clinicians. J Wound Ostomy Continence Nurs. 2010;37:596-8.

5. Scardillo J, Dunn KS, Piscotty R Jr. Exploring the Relationship Between Resilience and Ostomy Adjustment in Adults With a Permanent Ostomy. J Wound Ostomy Continence Nurs. 2016;43:274-9.

6. Adam N, Rahbar S, Skinner R. Outcomes of Colostomy Reversal in a Public Safety Net Hospital: The End or Beginning of a New Problem? Am Surg. 2015;81:1084-7.
7. Salamone G, Licari L, Agrusa A, Romano G, Cocorullo G, Falco N, et al. Usefulness of ileostomy defunctioning stoma after anterior resection of rectum on prevention of anastomotic leakage A retrospective analysis. Ann Ital Chir 2016;87:155-60.

8. Kristensen SA, Jensen BT. Testing inter-rater reliability of the Urostomy Education Scale. Eur J Oncol Nurs. 2016;20:17-23.

9. Martinez CA, de Almeida MG, da Silva CM, Ribeiro ML, da Cunha FL, Rodrigues MR, et al. Enemas with $\mathrm{N}$-acetylcysteine can reduce the level of oxidative damage in cells of the colonic mucosa diverted from the faecal stream. Dig Dis Sci. 2013;58:3452-9.

10. Caltabiano C, Máximo FR, Spadari AP, da Conceição Miranda DD, Serra MM, Ribeiro ML, et al. 5-aminosalicylic acid (5-ASA) can reduce levels of oxidative DNA damage in cells of colonic mucosa with and without fecal stream. Dig Dis Sci. 2011;56:1037-46.

11. Martinez CA, Ribeiro ML, Gambero A, Miranda DD, Pereira JA, Nadal SR The importance of oxygen free radicals in the etiopathogenesis of diversion colitis in rats. Acta Cir Bras. 2010;25:387-95. 
12. Halliwell B. Biochemistry of oxidative stress. Biochem Soc Trans. 2007;35(Pt 5):1147-1150.

13. Pero RW, Roush GC, Markowitz MM, Miller DG. Oxidative stress, DNA repair, and cancer susceptibility. Cancer Detect Prev. 1990;14:555-61.

14. Davies KJ. Oxidative stress: the paradox of aerobic life. Biochem Soc Symp. 1995;61:1-31.

15. Porter NA, Caldwell SE, Mills KA. Mechanisms of free radical oxidation of unsaturated lipids. Lipids. 1995;30:277-90.

16. Esterbauer H, Schaur RJ, Zollner H. Chemistry and biochemistry of 4-hydroxynonenal, malonaldehyde and related aldehydes. Free Radic Biol Med. 1991;11:81-128.

17. Banerjee M, Kang KH, Morrow JD, Roberts LJ, Newman JH. Effects of a novel prostaglandin, 8-epi-PGF2 alpha, in rabbit lung in situ. Am J Physiol. 1992;263(3Pt 2):H660-663.

18. Rivett AJ. Regulation of intracellular protein turnover: covalent modification as a mechanism of marking proteins for degradation. Curr Top Cell Regul. 1986;28:291-337.

19. Beal MF. Oxidatively modified proteins in aging and disease. Free Radic Biol Med. 2002;32:797-803.

20. Kharitonov SA, Barnes PJ. Nitric oxide, nitrotyrosine, and nitric oxide modulators in asthma and chronic obstructive pulmonary disease. Curr Allergy Asthma Rep. 2003 3:121-9.
21. Thowfeik FS, AbdulSalam SF, Wunderlich M, Wyder M, Greis KD, Kadekaro AL, et al. A ROS-Activatable Agent Elicits Homologous Recombination DNA Repair and Synergizes with Pathway Compounds. Chembiochem. 2015;16: 2513-21.

22. Hussain SP, Harris CC. Molecular epidemiology of human cancer: contribution of mutation spectra studies of tumor suppressor genes. Cancer Res. 1998;58:4023-37.

23. Longatti TS, Acedo SC, de Oliveira CC, Miranda DD, Priolli DG, Ribeiro ML, et al. Inflammatory alterations in excluded colon in rats: a comparison with chemically induced colitis. Scand J Gastroenterol. 2010;45:315-24.

24. Nassri CGG, Nassri AB, Favero E, Rotta CM, Martinez CAR, Margarido NF. Influence of irrigation of nutritional solutions in the colon excluded of fecal stream: experimental study in rats. Rev Bras Colo-Proctol. 2008;28:306-14.

25. Pravda J. Radical induction theory of ulcerative colitis. World J Gastroenterol. 2005;11:2371-84.

26. Naito Y, Takagi T, Yoshikawa T. Neutrophil-dependent oxidative stress in ulcerative colitis. J Clin Biochem Nutr. 2007;41:18-26.

27. Kruidenier L, Verspaget HW. Review article: oxidative stress as a pathogenic factor in inflammatory bowel disease: radicals or ridiculous. Aliment Pharmacol Ther. 2002;16:1997-2015.

28. Rezaie A, Parker RD, Abdollahi M. Oxidative stress and pathogenesis of inflammatory bowel disease: an epiphenomenon or the cause? Dig Dis Sci. 2007;52:2015-21. 